\title{
Primary aneurysmal bone cyst of coronoid process
} Amit Goyal*1, Isha Tyagi ${ }^{1}$, Rajan Syal1, Tanu Agrawal² and Manoj Jain ${ }^{2}$

\author{
Address: ${ }^{1}$ Neuro-otology Unit, Department of Neuro-surgery, Sanjay Gandhi Post Graduate Institute of Medical Sciences, Raibareily Road, \\ Lucknow (Uttar Pradesh) - 226 014, India and 2Department of Pathology, Sanjay Gandhi Post Graduate Institute of Medical Sciences, Raibareily \\ Road, Lucknow (Uttar Pradesh) - 226 014, India \\ Email: Amit Goyal* - meetugoyal@yahoo.com; Isha Tyagi - ityagi@sgpgi.ac.in; Rajan Syal - rajans@sgpgi.ac.in; \\ Tanu Agrawal - tanu@sgpgi.ac.in; Manoj Jain - mjain@sgpgi.ac.in \\ * Corresponding author
}

Published: I4 March 2006

BMC Ear, Nose and Throat Disorders2006, 6:4 doi:10.1186/1472-68/5-6-4

This article is available from: http://www.biomedcentral.com//472-68/5/6/4

(c) 2006Goyal et al; licensee BioMed Central Ltd.

This is an Open Access article distributed under the terms of the Creative Commons Attribution License (http://creativecommons.org/licenses/by/2.0), which permits unrestricted use, distribution, and reproduction in any medium, provided the original work is properly cited.
Received: 17 December 2005

Accepted: 14 March 2006

\begin{abstract}
Background: Aneurysmal bone cysts are relatively uncommon in the facial skeleton. These usually affect the mandible but origin from the coronoid process is even rarer. To the best of our knowledge, this is the first reported case of a coronoid process aneurysmal bone cyst presenting as temporal fossa swelling.
\end{abstract}

Case presentation: A 17 year old boy presented with a progressively increasing swelling in the left temporal region developed over the previous 8 months. An expansile lytic cystic lesion originating from the coronoid process of the left mandible and extending into the infratemporal and temporal fossa regions was found on CT scan. It was removed by a superior approach to the infratemporal fossa.

Conclusion: Aneurysmal bone cyst of the coronoid process can attain enormous dimensions until the temporal region is also involved. A superior approach to the infratemporal fossa is a reasonable approach for such cases, providing wide exposure and access to all parts of the lesion and ensuring better control and complete excision.

\section{Background}

Aneurysmal bone cyst (ABC) usually affects long bones of the body and its involvement of facial bones is relatively rare. Mandible is usual site of involvement in facial skeleton but usually it originates from the region of body and ramus (in the region of molars) [1,2]. At few occasions, it is reported to be derived from the condyle also [3-5]. Involvement of coronoid process is quite rare.

There are few reports found in the literature describing involvement of coronoid process by $\mathrm{ABC}$ [6-8]. Mainly coronoid process was involved in one case [6], while ramus was also involved in the other one [7], and extensive involvement of ramus and condyle was also evident in one case [8]. Infratemporal fossa was involved in all these cases. They presented as cheek swelling or swelling in zygomatic region.

We report a case of $\mathrm{ABC}$ involving only coronoid process with infratemporal and temporal fossa extension. It presented to us as temporal fossa mass.

It adds one more aspect in diversity of clinical and biological behavior of $\mathrm{ABC}$ in maxillofacial region. 

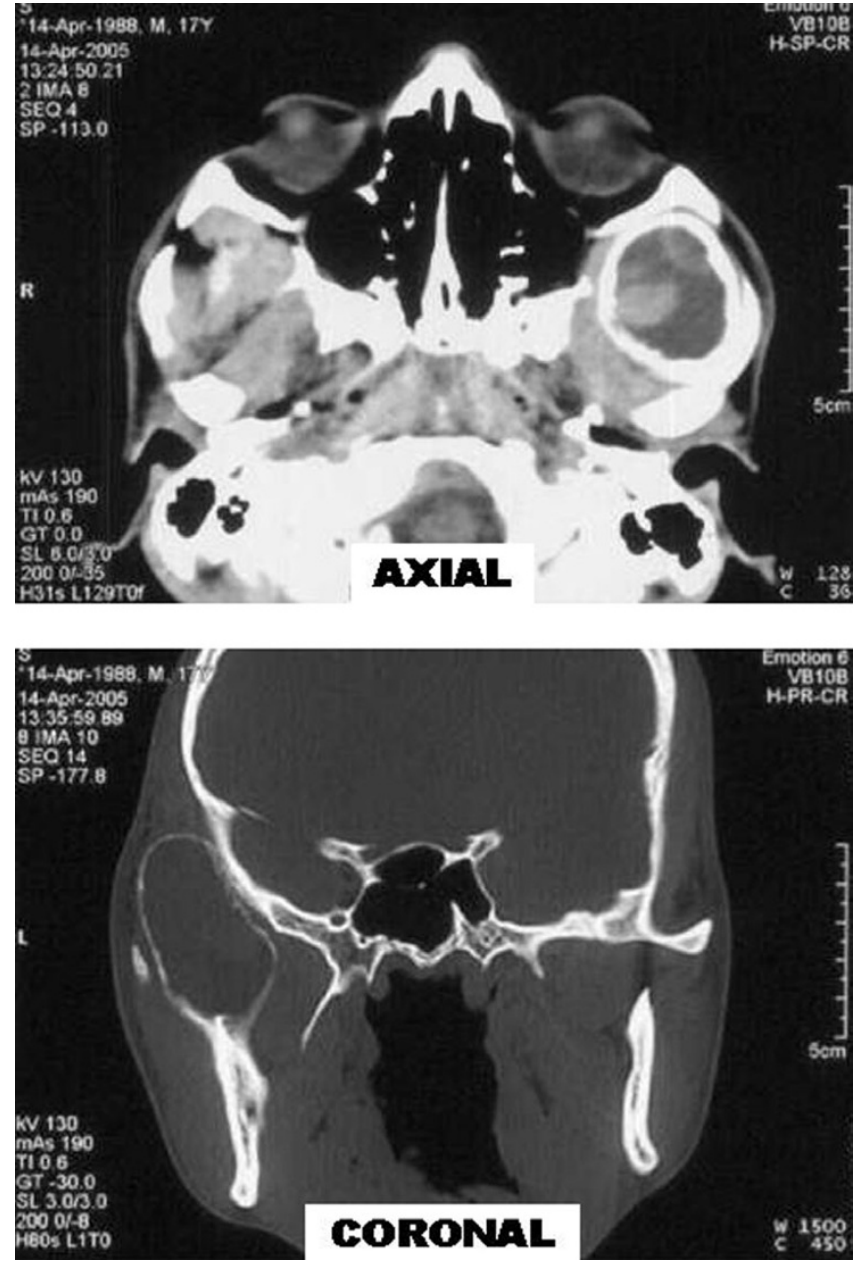

Figure I

Axial and coronal sections of CT scan showing rounded expansile lesion of bone with cortical thinning, mostly occupied by hypodense fluid with scattered areas of hyperdensity with in it.

\section{Case presentation Case report}

A 17 years male patient presented to us with the complaint of swelling in the left side temple since 8 months. There was mild pain on pressing the swelling and on opening of mouth. Swelling was progressively increasing in size. There was no other complaint.

On examination, there was about $3 \times 3 \mathrm{~cm}$ bony swelling in the left temporal fossa with facial asymmetry due to lateral bowing of left zygoma. It was immobile, slightly tender with egg shell crackling on pressure. There was no murmur or bruit on auscultation. There was no restriction to mouth opening. Lower part of the swelling could be palpated on digital palpation through mouth along the superior part of anterior border of ramus of left mandible.
On aspiration, brownish serous fluid came out. It contained mainly red blood cells.

CT scan of head and face (Figure 1) revealed rounded expansile lesion of bone with cortical thinning and few areas of cortical erosion. Lesion was originating from coronoid process of left mandible and was extending into the left infratemporal and temporal fossa. Lesion was mostly occupied by hypodense fluid with scattered areas of hyperdensity within it suggestive of haemorrhage.

This cystic mass was removed by superior approach to infratemporal fossa. A "Question mark" shaped incision was given within the hair line, starting $5 \mathrm{~cm}$ posterosuperior to lateral end of left supraorbital ridge, curving superiorly and posteriorly and coming down vertically to preauricular area. We went directly up to temporalis fascia and incised it. Then we dissected in the plane deep to it. There was a large cyst with papery thin brownish walls filled with brownish serous fluid (Figure 2). Arch of zygoma was cut at anterior and posterior ends. It was then retracted laterally and downwards to expose the infratemporal part of the cyst as done in Fisch D1 approach. Cyst was removed by following it downwards. Cyst was removed completely. The coronoid process was drilled with diamond burr to minimize the chances of recurrence.

Histopathological examination (Figure 3) shows numerous variably sized blood filled spaces separated by fibrous septae containing spindle shaped cells and scattered multinucleated giant cells.

\section{Discussion}

$\mathrm{ABC}$ is a pseudocyst lacking true epithelial lining and usually affecting long bones (50\%) and vertebrae (20\%) [3]. In facial skeleton, its occurrence is rare with mandible being affected more than maxilla (3:1) affecting mainly molar regions $[1,2]$. It accounts for $1.5 \%$ of the nonodontogenic, nonepithelial cysts of the mandible [9]. The mean age of involvement in skull and facial region is reported to be 14.3 years [10] with no sex predilection [1].

It is being recognized since 1893, but in 1942 Jaffe and Lichtenstein coined the term aneurysmal cyst which was changed to aneurysmal bone cyst in 1950 [3]. It is an expansile osteolytic pseudocyst which can attain great dimensions and may cause symptoms owing to its site and size and rapidity of growth i.e. swelling, deformity, pain, neurologic symptoms, and pathologic fractures.

Aneurysmal bone cyst is most common in those regions of the skeleton where there is both a relatively high venous pressure and high marrow content [11]. This explains rarity of $\mathrm{ABC}$ in the skull bones in which there is 


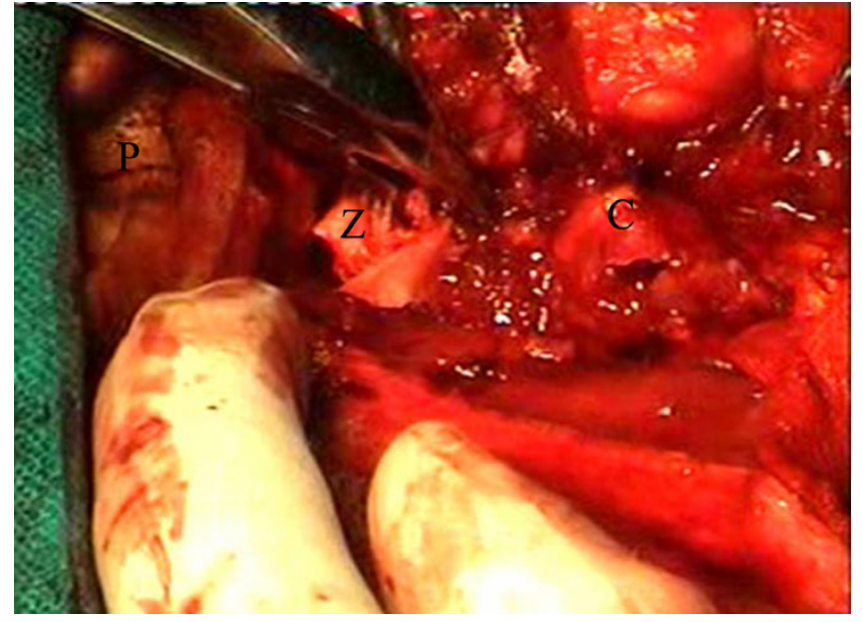

Figure 2

Peroperative photograph showing a thin walled cyst with brownish serous fluid coming out of it. ( $P=$ pinna, $Z=$ arch of zygoma, $\mathrm{C}=$ aneurysmal bone cyst)

low venous pressure. According to WHO, ABC is an "expanding osteolytic lesion consisting of blood-filled spaces of variable size separated by connective tissue septa containing trabeculae of osteoid tissue and osteoclast giant cells. "[12] Etiopathogenetically, it is thought to be a neoplasm, a developmental anomaly, or a response to trauma, chronic infection, arteriovenous anomalies or degenerative lesion $[2,13,14]$.

It can occur as a primary lesion or secondarily in a preexisting lesion. Martinez $\mathrm{V}$ and Sissons HA concluded that most of these cysts occur as a primary lesion [15]. Giant cell tumor is the most common lesion associated with secondary ABC accounting for 39\% of these lesions and similarly in $14 \%$ cases of giant cell tumor, ABC components are seen. Murphey MD et al has detailed radiopathologic correlations of ABC and giant cell tumor [16]. The other associated lesions are unicameral cyst, nonossifying fibroma, osteoblastoma, hemangioma, histiosarcoma, hemangioendothelioma, fractures and trauma [2].

In our case, there was no history or evidence of any other associated lesion. So we label it a case of primary $\mathrm{ABC}$ of coronoid process of mandible.

There are various treatment options suggested in the literature ranging from percutaneous sclerotherapy, diagnostic and therapeutic embolization, curettage, block resection and reconstruction, radiotherapy and systemic calcitonin therapy. Self healing cases have also been reported on long term follow up [17].

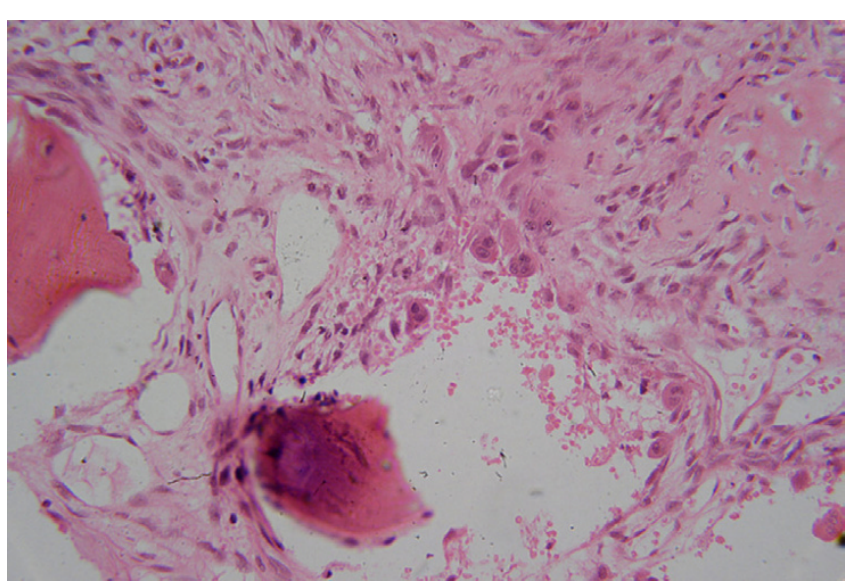

Figure 3

Microphotograph showing vascular spaces separated by septa containing giant cells and fibroblasts. (H\&E 250x)

Dubois et al [18] reported good results with sclerotherapy, but there is no material available for histological confirmation and diagnosis is solely bases on clinical and radiological evidences in many cases in his series. He considered histological confirmation not mandatory for the diagnosis. It may miss many associated lesions. Furthermore he considered a copious blood return through the first puncture a necessary requisite for diagnosis; it may misdiagnose a case like ours where only brownish serous fluid came out from the cyst.

Embolization of the feeding vessels has been shown to be effective as a preoperative procedure to reduce peroperative bleeding or after surgical failure. It is also employed as a sole treatment modality. But ABC frequently lacks large feeding vessels therefore may require repeated sittings for embolization [19].

Radiation was not considered for this patient looking at his age and surgically accessible tumor.

We chose superior approach to infratemporal fossa as it had some distinct advantages in this case. We could approach temporal, infratemporal regions as well as origin of the $\mathrm{ABC}$ with single incision. There were minimum chances of injury to facial nerve. With this incision, we could approach infratemporal fossa and coronoid process from laterally also in case of need.

There was no excessive bleeding from the cyst in our case.

\section{Conclusion}

- We presented first reported case of primary ABC from coronoid process of the mandible presenting as temporal swelling. 
- Superior approach to infratemporal fossa is a reasonable approach while managing such cases providing wide exposure and access to almost all parts of the lesion with flexibility of surgical approach in case of need with the same incision.

- We conclude that even after relatively smaller area of bone involvement and without surrounding destruction; $\mathrm{ABC}$ of coronoid process can attain enormous dimensions to present as swelling of a distant region which is more important in relatively compact maxillofacial region with regards to symptoms and management.

\section{Competing interests}

The author(s) declare that they have no competing interests.

\section{Authors' contributions}

All five authors

1) Have made substantial contributions in management of this case and in conception, design, analysis and interpretation of results of this case report

2) Have been involved in drafting the article or revising it critically for important intellectual content.

3) Have given final approval to the version to be published

\section{Acknowledgements}

Written consent was obtained from the patient and his parents for publication of the patient's details.

\section{References}

I. Motamedi MH, Yazdi E: Aneurysmal bone cyst of the jaws: Analysis of I I cases. J Oral Maxillofac Surg 1994, 52(5):47 I-5.

2. Struthers P, Shear M: Aneurysmal bone cyst of the jaws. Part II: Pathogenesis. Int J Oral Surg 1984, 13(2):92-100.

3. Gadre KS, Zubairy RA: Aneurysmal bone cyst of the mandibular condyle: report of a case. J Oral Maxillofac Surg 2000, 58(4):439-43.

4. Motamedi MH: Destructive aneurysmal bone cyst of the mandibular condyle: report of a case and review of the literature. J Oral Maxillofac Surg 2002, 60(I I):1357-6I.

5. Telfer MR, Jones GM, Pell GM, Eveson JW: Primary bone cyst of the mandibular condyle. $\mathrm{Br} J$ Oral Maxillofac Surg 1990, 28(5):340-3.

6. Matsuura S, Tahara T, Ro T, Masumi T, Kasuya H, Yokota T: Aneurysmal bone cyst of the coronoid process of the mandible. Dentomaxillofac Radiol 1999, 28(5):324-6.

7. Martins WD, Fávaro DM: Aneurysmal Bone Cyst of the Coronoid Process of the Mandible: A Case Report. J Contemp Dent Pract 2005, (6)2:130-8.

8. Rapidis $A D$, Vallianatou $D$, Apostolidis C, Lagogiannis G: Large lytic lesion of the ascending ramus, the condyle, and the infratemporal region. J Oral Maxillofac Surg 2004, 62(8):996-I00I.

9. Wiatrak BJ, Myer CM 3rd, Thomas MA: Alternatives in the management of aneurysmal bone cysts of the mandible. Int $J$ Pediatr Otorhinolaryngol 1995, 3 I (2-3):247-57.

10. Vergel De Dios AM, Bond JR, Shives TC, McLeod RA, Unni KK: Aneurysmal bone cyst: A clinicopathologic study of 238 cases. Cancer 1992, 69( I 2):2921-3I.
II. Boyd RC: Aneurysmal bone cysts of the jaws. Br J Oral Surg 1979, 16(3):248-53.

12. Schajowicz F: Histological typing of bone tumours. Berlin: Springer Verlag; 1992:37.

13. Oz G, Dolanmaz D, Uckan S, Gunhan O, Armstrong JW: Persistent Painful Swelling in the Posterior Mandible. J Oral Maxillofac Surg 2004, 62(9): I 139-43.

14. Karabouta I, Tsodoulos S, Trigonidis G: Extensive aneurysmal bone cyst of the mandible: Surgical resection and immediate reconstruction. A case report. Oral Surg Oral Med Oral Pathol 1991, 71 (2): I48-50.

15. Martinez V, Sissons HA: Aneurysmal bone cyst: A review of I 23 cases including primary lesions and those secondary to other bone pathology. Cancer 1988, 6I(II):2291-304.

16. Murphey MD, Nomikos GC, Flemming DJ, Gannon FH, Temple HT, Kransdorf MJ: Imaging of Giant Cell Tumor and Giant Cell Reparative Granuloma of Bone: Radiologic-Pathologic Correlation. RadioGraphics 200I, 2I(5): 1283-309.

17. Malghem J, Maldague B, Esselinck XW, Noel H, De Nayer P, Vincent $A$ : Spontaneous healing of aneurysmal bone cysts: $A$ report of three cases. J Bone Joint Surg Br 1989, 7 I (4):645-50.

18. Dubois J, Chigot V, Grimard G, Isler M, Garel L: Sclerotherapy in aneurysmal bone cysts in children: a review of 17 cases. Pediatr Radiol 2003, 33(6):365-72.

19. Boriani S, De lure F, Campanacci L, Gasbarrini A, Bandiera S, Biagini R, Bertoni F, Picci P: Aneurysmal bone cyst of the mobile spine: report on 4 I cases. Spine 200I, 26(I):27-35.

\section{Pre-publication history}

The pre-publication history for this paper can be accessed here:

\section{http://www.biomedcentral.com/1472-6815/6/4/prepub}

Publish with Biomed Central and every scientist can read your work free of charge

"BioMed Central will be the most significant development for disseminating the results of biomedical research in our lifetime. "

Sir Paul Nurse, Cancer Research UK

Your research papers will be:

- available free of charge to the entire biomedical community

- peer reviewed and published immediately upon acceptance

- cited in PubMed and archived on PubMed Central

- yours - you keep the copyright

Submit your manuscript here:

http://www.biomedcentral.com/info/publishing_adv.asp
BioMedcentral 